\title{
Fatty acids and sterols of Griffonia seeds oil
}

\author{
By Georgi Petkov ${ }^{\mathrm{a}}$ and Zakir Ramazanov ${ }^{\mathrm{b}}$
}

${ }^{a}$ Institute of Plant Physiology, Bulgarian Academy of Sciences, bl.21, 1113-Sofia, Bulgaria.

Tel.: 03592979 2109. Fax: 35927399 52. e-mail: gpdalg@bgcict.acad.bg.

${ }^{\mathrm{b}}$ Pharmline Inc., 41 Bridge Street,P.O.Box 291, Florida, New York 10921-0291, USA.

\section{RESUMEN}

Ácidos grasos y esteroles de aceite de semillas de Griffonia.

Se han estudiado los lípidos, ácidos grasos y esteroles del aceite de semillas de Griffonia simplicifolia. La composición en ácidos grasos es 18:2 - 60\%, 16:0, 18:0, 18:1 - 9-18\%, y 20:0 - 3$4 \%$. El principal esterol es el B-sitosterol - $60 \%$, el estigmasterol constituye el $29 \%$, y el campesterol el $11 \%$. El ácido linoleico puede enriquecerse hasta el 95\% separando los otros ácidos grasos como aductos de urea.

PALABRAS-CLAVE: Ácidos grasos - Esteroles - Griffonia Lípidos.

\section{SUMMARY}

Fatty acids and sterols of Griffonia seeds oil.

Lipids, fatty acids and sterols of Griffonia simplicifolia seeds oil were studied. Fatty acid composition is $18: 2$ - $60 \%, 16: 0,18: 0$, $18: 1-9-18 \%$, and $20: 0-3-4 \%$. The main sterol is B-sitosterol $60 \%$, stigmasterol is $29 \%$, and campesterol is $11 \%$. Linoleic acid can be relatively simply enriched to $95 \%$ separating the other fatty acids as urea adducts.

KEY-WORDS: Fatty acids - Griffonia - Lipids - Sterols.

\section{INTRODUCTION}

The West African legume plant Griffonia simplicifolia Baill. (Caesalpinaceae) has been studied intensively since 1960. Lectins and hydroxytriptophan were detected, and these substances constitute the main interest to the plant (1). There are no data about the seeds oil.

The aim of this paper is to study the lipid, fatty acid, and the sterol composition of G. simplicifolia seeds oil.

\section{MATERIALS AND METHODS}

\subsection{Materials}

The plants G. simplicifolia were cultivated in their native land Ghana. The seeds were commercial product of Pharmline Inc. and the oil samples of the seeds were kindly supplied by the farm. Three, light yellow oil samples from different seed batches extracted with liquid $\mathrm{CO}_{2}$ were analysed.

\subsection{Methods}

\subsubsection{Triacylglycerols}

Triacylglycerols (TG) were separated from the oil by thin layer chromatography (TLC) on silica gel G with hexane - diethyl ether $(3: 1 \mathrm{v} / \mathrm{v})$. The spots were identified using reference compounds and quantified densitometrically. Plates were sprayed with $\mathrm{H}_{2} \mathrm{SO}_{4}$ ethanol $(2: 3 \mathrm{v} / \mathrm{v})$ and heated at $110^{\circ} \mathrm{C}$ to visualise the spots.

\subsubsection{Fatty acids}

The oil samples were converted to fatty acid methyl esters by heating in methanol containing $6 \%$ $\mathrm{m} / \mathrm{m}$ anhydrous $\mathrm{HCl}$ at $60^{\circ} \mathrm{C}$ for $1.5 \mathrm{~h}$. The fatty acid methyl esters were extracted with hexane and purified by TLC on silica gel with hexane - diethyl ether (10:1 $\mathrm{v} / \mathrm{v})$.

\subsubsection{Sterols}

Another part of the oil sample was saponified with 5 $\% \mathrm{~m} / \mathrm{v} \mathrm{KOH}$ in $96 \% \mathrm{v} / \mathrm{v}$ ethanol for $2 \mathrm{~h}$ under reflux. Unsaponifiable matter was extracted with diethyl ether and gravimetrically quantified. Sterols were separated on TLC with hexane - diethyl ether (1:1 v/v).

\subsubsection{Purification of linolic acid}

A mixture of 1 part fatty acid methyl esters, 10 parts urea, and 30 parts ethanol was heated for several minutes until dissolution, and then slowly cooled to obtain the solid urea adducts. The crystals were isolated and the solution was extracted with hexane, evaporated and analysed by gas chromatography.

\subsubsection{Gas chromatography}

Gas chromatography of fatty acid methyl esters was carried out on $10 \%$ DEGS and $2.5 \%$ SE-52, 
$1.82 \mathrm{~m}$ packed columns at $190^{\circ} \mathrm{C}$. Sterols were separated on a $12 \mathrm{~m}$ long OV-17 capillary column at $210^{\circ}-270^{\circ} \mathrm{C}$ with a rate of $5 / \mathrm{min}$. All of the fatty acid methyl esters and sterols were identified using reference substances, and performed on a Perkin-Elmer gas chromatograph with flame ionization detector.

\section{RESULTS AND DISCUSSION}

The lipid composition of G. simplicifolia seeds was studied (Table I). The oil contains predominantly TG. Small amount of polar lipids remains near to the start of TLC of TG. The visualised spot has a retention factor equal to lecithin. The samples from different batches have one and the same qualitative and very similar quantitative composition.

The percentage of fatty acids of different samples remains relatively constant (Table II). Having used two GC columns - DEGS which separated fatty acids according to the number of their carbon atoms and double bonds, and SE-52 which separated according to the number of carbon atoms only, we confirmed this composition.

Sterols varied about $45 \%$ from the unsaponifiable substances. Their individual composition is presented in Table III. The rest of unsaponifiable substances are hydrocarbons, fatty alcohols, phytol, and small amount of xantophyls.

The fatty acid methyl esters, produced by transmethylation of the oil were treated with urea for separation of saturated fatty acids as adducts $(2,5)$. As a result we have enriched the mixture as follows: 18:2 - $95 \%$, 18:1 - $4 \%$, all others - $1 \%$. Using this relatively simple and technologically proper method we can achieve high percentage of linoleic acid. There are sources, whose original percentage of linoleic acid is greater but they can not be easily enriched to such a stage because of high percentage of oleic acid. So the oil of $G$. simplicifolia seeds can be a proper source of pure linoleic acid.

The results obtained demonstrate that the main fatty acids of Griffonia seeds oil are usual. Similarly to peanut oil and tomato seeds oil there is small amount of arachidic acid $(3,4)$. We can conclude, that the lipid and the fatty acid composition of the seeds of Griffonia are typical for a south thermophilic plant.

Table I

Percentage of lipids

\begin{tabular}{cc}
\hline Substances & $\%$ \\
\hline Triacylglycerols & $90-92$ \\
Unsaponifiable & $5-6$ \\
Polar lipids & $2-3$ \\
\hline
\end{tabular}

Table II

Percentage of fatty acids

\begin{tabular}{cc}
\hline Fatty acid & $\%$ \\
\hline $14: 0$ & tr. \\
$16: 0$ & $9-11$ \\
$18: 0$ & $16-18$ \\
$18: 1$ & $10-11$ \\
$18: 2$ & $53-60$ \\
$20: 0$ & $3-4$ \\
\hline
\end{tabular}

Table III

Percentage of sterols

\begin{tabular}{cc}
\hline Sterol & $\%$ \\
\hline Campesterol & 11 \\
Stigmasterol & 29 \\
$\beta$-Sitosterol & 60 \\
\hline
\end{tabular}

\section{REFERENCES}

1. Fellows, L. E. and Bell, E. A. (1970). 5-Hydroxy-I-triptophan, 5-Hydroxytryptamine and I-Tryptophan-5-hydroxylase in Griffonia simplicifolia. Phytochemistry 9, 2389-2396.

2. Gawalek, G. (1969). Einschlussverbindungen. VEB Deutscher Verlag der Wissenschaften, Berlin.

3. Giambastiani, G. and Casanoves, F. (2000). Composition lipidica de semillas de mani (Arachis hipogaea L.) obtenidas bajo diferentes conditiones de disponibilidad de agua. Grasas y Aceites 51, 412-416.

4. Popov, A and llinov, P. (1986). Chemistry of lipids Nauka i Iskustvo, Sofia.

5. Stefanov, K., Seisova, K., Popov, S. and Petkov, G. (1989). Method for obtaining of biological active polyunsaturated fatty acids Patent BG 46172.

Recibido: Septiembre 2001 Aceptado: Mayo 2002 